\title{
Foxp3 Serum Levels in Contrast Induced Nephrophaty Patients After the Administration of Contrast Media
}

\author{
Yuyun Widaningsih ${ }^{1}$, Rosdiana Natsir ${ }^{2}$, Mansyur Arif ${ }^{1}$, Uleng Bahrun ${ }^{1}$, Hasyim Kasim ${ }^{3}$, \\ Nursin Abdul Kadir ${ }^{1}$, Fitri Hamka ${ }^{1}$, Nadyah Haruna ${ }^{4}$, Mochammad Hatta ${ }^{5}$, \\ Andi Nilawati Usman ${ }^{6, *}$ \\ ${ }^{1}$ Department of Clinical Pathology, Hasanuddin University, Makassar City, Indonesia \\ ${ }^{2}$ Department of Biochemistry, Hasanuddin University, Makassar City, Indonesia \\ ${ }^{3}$ Department of Internal Medicine, Hasanuddin University, Makassar City, Indonesia \\ ${ }^{4}$ Department of Medicine, UIN Alauddin University, Makassar City, Indonesia \\ ${ }^{5}$ Department of Immunology and Biomolecular, Hasanuddin University, Makassar City, Indonesia \\ ${ }^{6}$ Halal Center of Public Health, Hasanuddin University, Makassar City, Indonesia
}

\section{Email address:}

yuyunwidaningsih@yahoo.com (Y. Widaningsih), rosdiananatsir@yahoo.com (R. Natsir), ulengbahrun68@yahoo.com (U. Bahrun), manyur_arif@yahoo.com (M. Arif), hasyimkasim@yahoo.com (H. Kasim),nursinak@gmail.com (N. A. Kadir), fitryhamka@gmail.com (F. Hamka),nadyaharuna@gmail.com (N. Haruna), hattaram@indosat.net.id (M. Hatta), nilawatiandi@gmail.com (A. N. Usman)

${ }^{*}$ Corresponding author

\section{To cite this article:}

Yuyun Widaningsih, Rosdiana Natsir, Mansyur Arif, Uleng Bahrun, Hasyim Kasim, Nursin Abdul Kadir, Fitri Hamka, Nadyah Haruna, Mochammad Hatta, Andi Nilawati Usman. Foxp3 Serum Levels in Contrast Induced Nephrophaty Patients After the Administration of Contrast Media. International Journal of Biomedical Materials Research. Vol. 5, No. 2, 2017, pp. 25-28. doi: 10.11648/j.ijbmr.20170502.12

Received: April 4, 2017; Accepted: May 22, 2017; Published: June 1, 2017

\begin{abstract}
Percutaneous Coronary Intervention (PCI) procedure increases the risk of inflammation risk and represents adverse effects to immune system in the human body. One of the functions in the human body in maintaining the balance of immune system is Foxp3 of regulatory T cells and the function of Foxp3 is seldom to be the subject of study in coronary patients from the administration of contrast agents after PCI. This study was conducted to analyze the comparison Foxp3 levels of regulatory $\mathrm{T}$ cells in blood serums in patients who experienced contrast induced nephrophaty (CIN) after PCI procedure for both the CIN group and the non-CIN group. The population of coronary patients after PCI. The sample size was 20 patients that consisted of 10 patients who experienced CIN and 10 patients who experienced the CIN group. Categorization of both the CIN and non-CIN group used Kidney Disease Improving Global Outcomes (KDIGO) and detection of Foxp3 levels in blood serums using Enzyme-linked immunosorbent assay (ELISA) technique. Result of this study indicated that the characteristics of patients between the CIN group and the non-CIN group did not reveal significant difference, except for the characteristic of age. Results of the analysis by using statistical pair and non-pair t-test showed that patients for both the CIN group and nonCIN group experienced significant reduction of Foxp3 levels of regulatory T cells in their blood serums. This indicated that the PCI procedure indeed led to inflammation and Foxp3 levels and it could not be used as the specific marker for CIN incidence, but it should be mediated by the inflammation marker.
\end{abstract}

Keywords: Percutaneous Coronary Intervention, Contrast Induced Nephrophaty, Foxp3

\section{Introduction}

Contrast induced nephropaty (CIN) is one of the foremost factors for the high risk of acute kidney injury (AKI) incidence [1]. Administration of contrast media during percutaneous coronary intervention (PCI) at hospitals increases the risk of CIN incidence, although there have been any risks due to the ascending use of procedure of coronary intervention thorough the application of contrast media [2]. 
Contrast media has cytotoxic effects due to cytotoxity of iodine. Free, noncompelexed iodine $\left(\mathrm{I}_{2}\right)$ and its polarized form $\left(\mathrm{H}_{2} \mathrm{O} \mathrm{I}^{+}\right)$undergo interaction with amino acids found in cell membrane proteins, damaging them and causing loss of cell membrane integrity. Through similar processes, iodine may exert direct toxicity on vascular cells and renal tubular cells [3].

Phatogenesis involved in AKI incidence is inflammation and this condition is also take places in CIN. Vascular endotel disfunction may occur due to the increase of inflammatory mediators [4-6]. Regulatory $\mathrm{T}$ cells through its homeostasis function in immune system have protective function on renal and deliver a novel therapeutic target for AKI [6]. Theraphy through determination of regulatory $\mathrm{T}$ cells as the target has proven increase the improvement rate and restoration of renal functions. In addition, these regulatory $\mathrm{T}$ cells have proven useful in reducing inflammation by balancing proinflammatory cytokines and anti inflammation [7]. The biomarker used to detect regulatory $\mathrm{T}$ cells is Foxp3 as the transcption factor of regulatory $\mathrm{T}$ cells [8].

Roles and functions of AKI and results of search of literature revealed that this study that analyze the condition of regulatory $\mathrm{T}$ cells in CIN are seldom to be the subject of medical study that instigated the authors of this study to analyze Foxp3 levels of regulatory $\mathrm{T}$ cells for the $\mathrm{CIN}$ based on the consideration that this study has a valuable scientific contribution for the medical treatment of CIN and prevention of AKI.

\section{Materials and Methods}

Experimental design used in this study was cross sectional design for the population of cardiovascular patients who underwent PCI through the comparison between the CIN group and the non-CIN group. The total samples were 20 patients. All experimental procedures for the treatment of patients were reviewed and approved by the Research Ethics Committee of Medicine Faculty of Hasanuddin University as stated in the Recommendation of Research Ethics issued in the registration no. UH16090750.

Detection of CIN was conducted at the Clinical Pathology and Medical Laboratory at Hasanuddin University. CIN criteria referred to the Kidney Disease Improving Global Outcomes (KDIGO) of the year 2012 based on an increase in serum creatinine by either $\geq 0.5 \mathrm{mg} / \mathrm{dL}$ or by $\geq 25 \%$ from baseline within 48 hours from the administration of radiographic contrast media after other causes of renal impairment have been excluded.

\subsection{Detection of Foxp3 Levels of Regulatory T Cells}

Samples to determine Foxp3 levels of regulatory $\mathrm{T}$ cells were blood serums. Each sample consisted of $3 \mathrm{ml}$ of blood of patients. Detection of Foxp3 levels of regulatory T cells in blood serums used Human Kit ELISA of the lifespan biosciences (LSBio) and the standard procedure set in the LSBio.

This test used the enzyme-linked immunoabsorbant assay (ELISA) technique. Each well of a microtiter plate was stained with antibodies specific to Foxp $3^{+}$. Standard samples were put into the wells and the samples that contained Foxp $3^{+}$formed chemical bonds with capture antibodies. Standard sampels that did not form chemical bonds with capture antibodies were excluded by washing. Biotin conjugated antibodies were then added later to form chemical bonds with antigens.

Antibodies that did not form chemical bonds with antigens were excluded by washing. Avidin conjugated to Horseradish Peroxidase (HRP) were then put into each well and were then incubated. Avidin-HRP Conjugate was then formed chemical bonds with biotin. Samples that did not form chemical bonds with Avidin-HRP Conjugate were excluded by washing. After substrats of TMB were added, only wells that contained Foxp $3^{+}$, biotin-conjugated antibody and conjugated avidin enzymes underwent the alteration of colors. Substrateenzyme reactions were discontinued by added sulphuric acid solution and the alteration of colors was measured using spektrofotometer at the $450 \mathrm{~nm} \pm 10 \mathrm{~nm}$ wavelengths. Foxp $3^{+}$concentrations in samples were then measured through the comparison between Optical Density (OD) in the treated samples and the OD in the standard.

\subsection{Statistic Analysis}

The experimental data were represented in the form tables that included mean and standard deviation. The statistical test used to determine the mean difference of between the CIN group and the non-CIN group was independent-t test. Mean difference values before and after the treatment.

\section{Results}

Cardiovascular patients who were administered by contrast media were classified into both the CIN and the non-CIN groups based on the category of KDIGO. Table 1 that indicated the characteristics for the CIN group and the nonCIN group did not show statistically significant difference in baseline characteristics, except for the age. Patients in the CIN group had higher mean age.

Table 1. Baseline Characteristics of Samples for both the CIN and the nonCIN Groups.

\begin{tabular}{|c|c|c|c|c|}
\hline \multirow[b]{2}{*}{ Characteristic } & & \multicolumn{2}{|l|}{ Groups } & \multirow[b]{2}{*}{$p$} \\
\hline & & $\begin{array}{l}\text { Non-CIN } \\
(n=10)\end{array}$ & $\begin{array}{l}\text { CIN } \\
(n=10)\end{array}$ & \\
\hline \multirow[t]{2}{*}{ Gender } & Male & $9(90 \%)$ & $9(90 \%)$ & \multirow{2}{*}{$1.000 *$} \\
\hline & Female & $1(10 \%)$ & $1(10 \%)$ & \\
\hline \multirow[t]{2}{*}{ Diagnosis } & CAD 1 & $6(60 \%)$ & $4(40 \%)$ & \multirow{3}{*}{$0.558 *$} \\
\hline & CAD 2 & $2(20 \%)$ & $1(10 \%)$ & \\
\hline \multirow{3}{*}{ Complication } & CAD 3 & $2(20 \%)$ & $5(50 \%)$ & \\
\hline & $\begin{array}{l}\text { Diabetes } \\
\text { mellitus }\end{array}$ & $1(10 \%)$ & $6(60 \%)$ & 0.400 \\
\hline & Hypertension & $1(10 \%)$ & $8(80 \%)$ & 0.467 \\
\hline $\begin{array}{l}\text { Age } \\
(\text { Mean } \pm \text { SD) } \\
\text { Year }\end{array}$ & & $45.00 \pm 9.75$ & $59.00 \pm 5.06$ & $0.002 * *$ \\
\hline
\end{tabular}

Comparative analysis for Foxp3 levels s of regulatory $\mathrm{T}$ 
cells in serums between the CIN group and the non-CIN group indicated that patients for the two groups collectively experienced the reduction of Foxp3 levels of regulatory $\mathrm{T}$ cells after the administration of contrast media in which patients of the non-CIN group had higher reduction than the CIN group although the CIN group also had statistically significant reduction (Table 2).

Table 2. Comparison of Foxp3 levels of regulatory T cells in serums between the CIN Group and non-CIN Group.

\begin{tabular}{lllll}
\hline \multirow{2}{*}{ Groups } & \multicolumn{2}{l}{ Foxp3 levels of Regulatory T cells in Blood Serums (ng/ml) } & \multirow{2}{*}{ Mean Difference } & $\boldsymbol{p}$ \\
\cline { 2 - 3 } & Pre-treatment & Post-treatment & 2.79 & $0.000^{*}$ \\
\hline Non-CIN & $2.64+0.71$ & $5.43+0.55$ & 2.42 & $0.000^{*}$ \\
CIN & $1.55+0.51$ & $3.97+0.73$ & & \\
Mean difference & 1.09 & 1.46 & & \\
$p$ & $0.000^{* *}$ & $0.000^{* *}$ & \\
\hline
\end{tabular}

*Paired-t test

**Independent-t test

\section{Discussion}

The significant difference of characteristics between the CIN and the non-CIN is evidenced for the age characteristic, and age factor is indeed as the predictor for the CIN incidence among cardiovascular patients administered by contrast media $[9,10]$. Older patients face more risk the CIN incidence after the administration of contrast agents.

After PCI, Foxp3 levels of regulatory $\mathrm{T}$ cells in blood serums underwent significant reduction either at the CIN group or the Non-CIN group. PCI is considered has valuable effect due to its function to eliminate plugs, but other hand, this procedure may trigger inflammatory responses [11]. During inflammation, several proinflammatory cytokines that include tumor necrosis factor (TNF- $\alpha$ ) may suppress function of Foxp3 through some certain mechanisms that include reduction of phosporilization of Foxp3 [12, 13]. Migration of Foxp3 of regulatory $\mathrm{T}$ cells to the injured tissues may also to be the mechanism cause of the reduction of Foxp3 levels of regulatory $\mathrm{T}$ cells in serum at the area of periphery [14]. After PCI, this study is consistent with other studies that the increase of inflammation biomarkers lead to the damage of endotel that trigger coronary spams which in turn lead to aggregation of thrombosites $[15,16]$. This indicated that the PCI procedure indeed led to inflammation and Foxp3 levels and it could not be used as the specific marker for CIN incidence, but it should be mediated by the inflammation marker.

This study proved evidence that PCI procedure could cause adverse effect to the balance of immune system and to be the causal factor for the risk of renal failure. In addition to that, analysis of comparison between the CIN and non-CIN group indicated that although there were several patients did not experience CIN, PCI procedure still lead to significant effect to the reduction of Foxp3 levels of regulatory $\mathrm{T}$ cells. This study paves away to conduct further researches to study the effect of PCI on inflammation by detecting biomarkers of inflammation for both the CIN and non-CIN groups.

\section{Conclusion}

Reduction of Foxp3 levels of regulatory $\mathrm{T}$ cells in blood serums indicated that inflammation occurred after PCI procedure among patients who experienced $\mathrm{CIN}$ incidence or non-CIN and indicated that the PCI procedure indeed led to inflammation and Foxp3 levels and it could not be used as the specific marker for CIN incidence, but it should be mediated by the inflammation marker.

\section{References}

[1] Garcia, S., B. Ko, and S. Adabag, Contrast-induced nephropathy and risk of acute kidney injury and mortality after cardiac operations. Ann Thorac Surg, 2012. 94 (3): p. $772-6$.

[2] Shoukat, S., et al., Contrast-induced nephropathy in patients undergoing percutaneous coronary intervention. Cardiol Res Pract, 2010. 2010.

[3] Sadat, U., Radiographic contrast-media-induced acute kidney injury: pathophysiology and prophylactic strategies. ISRN Radiol, 2013. 2013: p. 496438.

[4] Schrier, R. W., et al., Acute renal failure: definitions, diagnosis, pathogenesis, and therapy. J Clin Invest, 2004. 114 (1): p. 5-14.

[5] Bonventre, J. V. and L. Yang, Cellular pathophysiology of ischemic acute kidney injury. J Clin Invest, 2011. 121 (11): p. 4210-21.

[6] Kinsey, G. R., R. Sharma, and M. D. Okusa, Regulatory T cells in AKI. J Am Soc Nephrol, 2013. 24 (11): p. 1720-6.

[7] Kinsey, G. R. and M. D. Okusa, Expanding role of T cells in acute kidney injury. Curr Opin Nephrol Hypertens, 2014. 23 (1): p. 9-16.

[8] Rudensky, A. Y., Regulatory T cells and Foxp3. Immunol Rev, 2011. 241 (1): p. 260-8.

[9] Chong, E., et al., Risk factors and clinical outcomes for contrast-induced nephropathy after percutaneous coronary intervention in patients with normal serum creatinine. Ann Acad Med Singapore, 2010. 39 (5): p. 374-80.

[10] Ando, G., et al., Age, glomerular filtration rate, ejection fraction, and the AGEF score predict contrast-induced nephropathy in patients with acute myocardial infarction undergoing primary percutaneous coronary intervention. Catheter Cardiovasc Interv, 2013. 82 (6): p. 878-85. 
[11] Munk, P. S., et al., Inflammatory response to percutaneous coronary intervention in stable coronary artery disease. J Thromb Thrombolysis, 2011. 31 (1): p. 92-8.

[12] Valencia, X., et al., TNF downmodulates the function of human CD4+CD25hi T-regulatory cells. Blood, 2006. 108 (1): p. 253-61.

[13] Nie, H., et al., Phosphorylation of FOXP3 controls regulatory $\mathrm{T}$ cell function and is inhibited by TNF-alpha in rheumatoid arthritis. Nat Med, 2013.19 (3): p. 322-8.
[14] Emoto, T., et al., Regulatory/Effector T-Cell Ratio Is Reduced in Coronary Artery Disease. Circulation Journal, 2014. 78 (12): p. 2935-2941.

[15] Salgado Filho, W., et al., [Intracoronary inflammatory markers after percutaneous coronary interventions]. Arq Bras Cardiol, 2005. 85 (3): p. $180-5$.

[16] Saadeddin, S. M. and M. A. Habbab, Percutaneous coronary intervention in the context of systemic inflammation: more injury and worse outcome. Med Sci Monit, 2003. 9 (8): p. Ra193-7. 